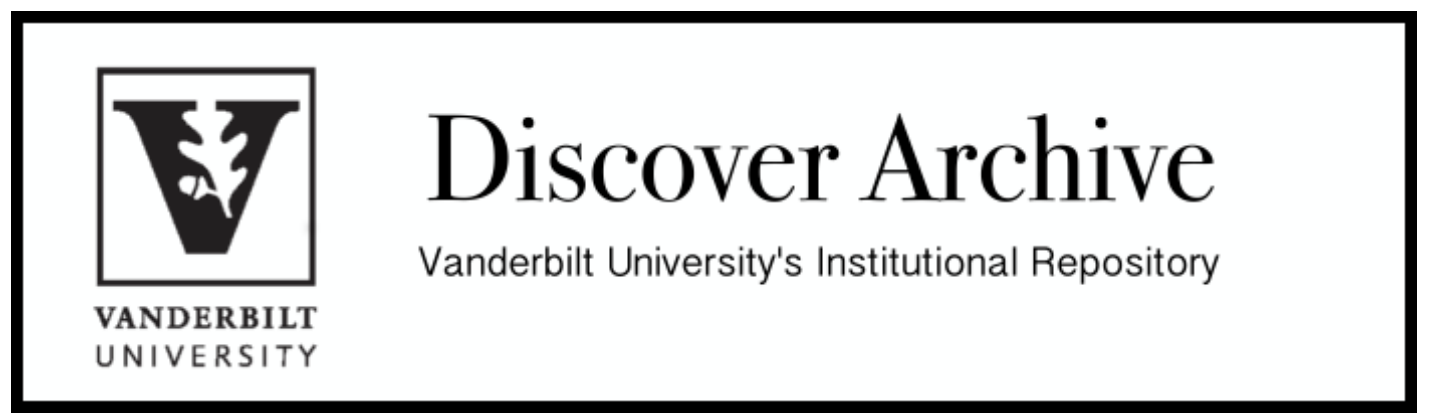

This work was originally published as: Suzanna Sherry, Using and Misusing History - 25 Reviews in American History 337 (1997). 


\title{
USING AND MISUSING HISTORY
}

\author{
Suzanna Sherry
}

Laura Kalman. The Strange Career of Legal Liberalism. New Haven: Yale University Press, 1996. viii +375 pp. Notes and index. $\$ 40.00$.

Since Alfred Kelly coined the term "law-office history" in 1965, not much has been added-except ever-multiplying examples-to the perennial complaints about how lawyers and legal academics use history. Laura Kalman's engaging new book about legal scholarship is thus a welcome contribution to the field.

Kalman begins by tracing the history of legal scholarship since the realists. The central conundrum the realists and their successors bequeathed to "legal liberals" - those who trust the courts to implement large-scale social reformwas how to keep their faith after the death of Earl Warren and subsequent attacks from both the Left and the Right. The first four chapters of the book are an accessible and enjoyable romp through legal realism, the legal process school, the "law and" movement, hermeneutics, and the various other scholarly fads that have entranced law professors over the years. Kalman provides nice insights into the relationships between law and other disciplines and tries, although not always successfully, to relate the various movements to legal liberalism and its travails. She is occasionally too glib, especially when attributing malevolent motives to legal liberals: she claims, for example, that the crisis of legal liberalism in the 1980s might have been triggered partly by the fear of "male academic lawyers ... that the entrance of women and people of color into their ranks challenged their control of the law schools" (p. 94).

This part of the book accomplishes several important goals. It provides an interesting and substantial history of modern legal scholarship. (I am perhaps not in the best position to assess this particular contribution, as it left me feeling a bit voyeuristic: I should disclose that my own work is mentioned quite prominently, to somewhat mixed reviews from Kalman.) Kalman is very good at this sort of history, and readers will come away with a deep understanding of the content and derivation of, and interrelationships between, the most important modern legal theories.

Even more important, however, is that Kalman's discussion of the ebb and

Reviews in American History 25 (1997) 337-340 @ 1997 by The Johns Hopkins University Press 
flow of legal liberalism provides a new and persuasive way to explain why lawyers do history the way they do (that is, according to most historians, badly). Kalman shows how legal liberalism-buffeted from both sides of the political spectrum and riven by internal division-was, by the mid-1980s, "dead, a historical relic" (p. 131). And so legal liberals turned to history for their salvation.

What they found there was civic republicanism. Kalman does a wonderful job of explaining how civic republicanism satisfied all the needs of legal liberals. It enabled them to fend off attacks from originalists on the right by providing "alternative interpretations of the Founding" (p. 139). It complemented the growing interest in communitarianism that legal liberals were borrowing from political theorists. It promised to reduce the increasing polarization of the legal academy by allowing a synthesis between individual rights and community bonds, especially once republicanism was purged of its less desirable attributes such as sexism, authoritarianism, and racism. Kalman charmingly describes this purging as an attempt "to create a kinder, gentler republicanism" (p. 160). The synthesis between individuals and community in turn offered a way out of the countermajoritarian dilemma that had haunted legal liberals since the Warren Court. It is no wonder the neorepublicans "possessed a missionary spirit" (p. 155).

But a religious mission is not the same as a historical one, and therein lies the key to the sometimes strained relationships between lawyers and historians. As Kalman puts it, "historians ... favor context, change, and explanation," and lawyers "value text, continuity, and prescription" (p. 180). Historians "delight in recreating the past in all its strangeness" (p. 186). For lawyers, however-especially neorepublicans on a mission-history is to be mined for its usefulness, not explored for its own sake. Legal liberals needed republicanism as a tool in their war against conservative originalists, and could not afford the ambiguities, contradictions, and occasional distasteful results inherent in a truly historical approach to the Founders' thought. So, Kalman explains, "historians entered the fray to police their territory" (p. 163). This was not a difficult goal, for, as Kalman points out, "it is as easy to show that lawyers' legal history is ahistorical as it is to shoot fish in a barrel" (p. 179).

Had Kalman's analysis stopped here, it would have contributed significantly to our understanding of legal liberalism. Perhaps her greatest insight, however, is her recognition that this is not the end of the story. She quotes Mark Tushnet that "it is not a lot of fun watching people shoot fish in barrels; indeed, one sometimes begins to develop sympathy both for the fish, who are doing the best they can in trying circumstances, and for their pursuers, who are doing the only thing they know how to do" (pp. 179-80). Kalman does in fact have great sympathy for both the lawyers and the historians, and seems to wish that each had a little more sympathy for the other. 
She conveniently provides suggestions for developing that mutual sympathy. There is a difference, Kalman suggests, between "scholarly history and 'public history' for nonacademic audiences" (including judges) (p. 202). The latter, while it should remain faithful to the goal of historical accuracy, may be less sophisticated, less ambiguous, and more forcefully stated. Historians should recognize that lawyers' legal history serves a different purpose than historians' legal history, and thus may not be as complex or nuanced. Lawyers, on the other hand, must nevertheless use history responsibly, becoming "more sensitive to the varieties of historical interpretation" (p. 206). She suggests a number of rules for responsible "public" scholarship, including that "the public historian's conclusion should not diverge from the scholar's" (p. 205). She offers as a cautionary example the case of women's historian Alice Kessler-Harris, whose own scholarship was used to rebut her testimony in a sex discrimination case.

One might generalize Kalman's sound advice to both lawyers and historians: never let your politics get in the way of your scholarship, whether public or academic. Indeed, the examples she gives of failures in both fields are often cases where a scholar was tripped up by an overwhelming desire to use (or abuse) scholarship to achieve a particular political result. Although not mentioned by Kalman, the current controversy over philosopher and classicist Martha Nussbaum's testimony in the suit challenging Colorado's antihomosexual constitutional amendment is another case in point. Nussbaum testified that the Greeks did not disapprove of homosexuality, relying primarily on her translation of the Greek description of homosexuality as tolmêma. While many experts give tolmêma a negative connotation by translating it as "enormity" or "shameless act," she testified that it had the neutral or positive connation of "daring," and that "enormity" was a mistranslation. Her goalto help invalidate a mean-spirited law later held unconstitutional by the United States Supreme Court-might have been laudable, but her means were questionable. She supported her testimony by referring to an outdated edition of the authoritative Greek dictionary. More recent editions include "enormity" among the definitions of tolmêma. Although Nussbaum claimed to use the older edition exclusively, it turns out that she regularly cites a more recent edition in her own scholarly work. Even if Nussbaum's translation of tolmêma is more accurate than that of the lexicon, she did herself no good by trying to finese the problematic entry. ${ }^{1}$

In the end, though, it is not clear whether Kalman really wants lawyers and historians to take her advice, because doing so might doom legal liberalism. In a puzzling final chapter called "Trading Places," she suggests that just as historians are becoming more willing to accept history-as-ammunition, lawyers are becoming more critical of ahistorical attempts at recasting the Founders' intent. One might expect Kalman to applaud the lawyers' move 
toward more responsible historical scholarship, but instead she seems to deplore it: she concludes the book by noting that "it would be unfortunate if law professors desert the barricades just as academics in other fields, such as historians, begin to show signs of appreciating what legal scholars are doing, and wanting to help" (p. 246).

Perhaps she is merely troubled that lawyers have gone too far, and no longer recognize the need for "public" legal history scholarship. She does note that "history can never do as much as law professors want" (p. 235). Unfortunately, however, her criticism of the liberal retreat from ahistorical originalism is subject to misinterpretation. She seems to value liberal originalism primarily as a powerful tool against conservative originalism: in arguments over constitutional interpretation, she says, "Madison trumps everyone" (p. 238). It is tempting, therefore, to read her condemnation of legal liberals' move away from originalism as inviting a perusal of Madison's voluminous and sometimes contradictory writings in search of support for the liberal position.

Would such an interpretation be misreading Kalman? To judge by the thoughtful analysis in most of the book, I believe that it would be. Kalman herself advocates a careful, responsible, and pragmatist approach, which sees a limited value in such arguments from history; she wouldnever countenance distortions of Madison's ideas even in the service of legal liberalism. But I am afraid she is expecting too much from most lawyers. She urges them to use what she recognizes as their most powerful weapon but to do so in moderation. Lawyers are, by training, disinclined to hold their fire; and liberal lawyers on a quasi-religious mission are doubly likely to read Kalman as urging them to (mis)use history for all it is worth.

Despite this danger, however, Kalman's book will enlighten both lawyers and historians. She notes that lawyers and historians have always talked at cross-purposes. Once historians scorned lawyers' attempts to use, rather than merely to understand, history; now, Kalman suggests, "it is the historians who are trying to be pragmatic, the law professors who want to be academic" (p. 229). Thus, having slid past one another without managing to meet in the middle, they are still engaged in "their dialogue of the deaf" (p. 229). What might remedy this deafness and provoke a serious and productive dialogue between historians and lawyers? I would suggest that both groups read Kalman's book. It might help them understand one another-and themselves.

Suzanna Sherry, Law School, University of Minnesota, is working on a book on postmodernism and law (forthcoming from Oxford University Press in 1997).

1. For a balanced and readable account of the whole controversy, see Daniel Mendelsohn, "The Stand: Expert Witnesses and Ancient Mysteries in a Colorado Courtroom," Lingua Franca (September/October 1996), at p. 35. 